\title{
Following the Flow
}

\author{
China's Approach to \\ Global Leadership
}

Obert Hodzi and

Chen Yu-Wen

\begin{abstract}
The liberal international order has been under heavy strain in recent years. From Brexit to Trump's presidency, its tenacity is being put to the test. The resultant commotion should be a window of opportunity for China to materially revise the existing order or establish an alternative order under its leadership. However, the puzzle that is unfolding but not yet significantly examined is that China is seemingly not taking advantage of the upheaval in the liberal international order to substantially revise the order or set up a new one. Premised on the metaphor of "following the flow," this paper argues that there is understandable rationale as to why
\end{abstract}

Obert Hodzi is Postdoctoral Researcher at the University of Helsinki, Finland. His research interests include Chinese foreign policy, emerging powers, South-South power dynamics, and governance in Africa. His mailing address is: Unioninkatu 38 B, FI00014, Helsinki, Finland. He can also be reached at obert.hodzi@helsinki.fi. Chen Yu-Wen is Professor of Chinese Studies at the University of Helsinki, Finland, Hosting Professor of Asian Studies at Palacky University, Czech Republic, as well as non-resident Senior Fellow at the China Policy Institute at the University of Nottingham, United Kingdom. Her mailing address is: Unioninkatu 38 A, FI00014, Helsinki, Finland. She can also be reached at julie.chen@ helsinki.fi.

(c) 2018 World Century Publishing Corporation and Shanghai Institutes for International Studies China Quarterly of International Strategic Studies, Vol. 4, No. 1, 1-21

DOI: $10.1142 / S 2377740018500045$

This is an Open Access article, copyright owned by the SIIS and WCPC. The article is distributed under the Creative Commons Attribution 4.0 (CC BY-NC) Licence. Further distribution of this work is permitted, provided the original work is properly cited and for non-commercial purposes. 
China is appearing to ignore the opportunity to establish a China-led global order. It then explores the approach in China's posture as protector of globalization and the liberal international order.

Keywords: China; liberal international order; window of opportunity; Donald Trump; global governance.

Donald Trump's presidency, combined with Brexit as well as the rise of ultra-nationalist parties in Europe and their inherent anti-globalization rhetoric, is putting the tenacity of the liberal international order to the test. ${ }^{1}$ By questioning the efficacy of globalization, extolling the break-up of the European Union (EU), disparaging U.S. military alliances in the AsiaPacific, and insinuating that the North Atlantic Treaty Organization (NATO) is outdated, Donald Trump has - within a year of his presidency - shaken the core foundations of the liberal international order that the United States has created and maintained since the end of World War II.

Withdrawal of the United States from the Trans-Pacific Partnership (TPP) and the Paris Agreement suggest, on the surface, that the country might be shaking off some of its global responsibilities in favor of strict and narrowly defined American interests. Furthermore, Trump's demand that the United States share the global security burden with its allies reflects an inflection point in U.S. foreign policy and a challenge to the idea that a global power "assumes certain burdens" ${ }^{2}$ and dispenses public goods and services, "such as security protection and support for open markets." ${ }^{3}$

While the United States, the main architect of the liberal international order, is challenging and seemingly non-committal to upholding the same order, China as a non-Western rising power is increasingly casting itself as a guarantor and protector of some aspects of the liberal international order, in particular, free trade and globalization. Premised on the metaphor of

${ }^{1}$ Brina Seidel and Laurence Chandy, "Donald Trump and the Future of Globalization," Brookings Institution, November 18, 2016, https://www.brookings.edu/blog/up-front/2016/ 11/18/donald-trump-and-the-future-of-globalization/.

2Stewart Patrick, "World Order: What, Exactly, Are the Rules?," Washington Quarterly, Vol. 39, No. 1 (2016), pp. 7-27.

${ }^{3} \mathrm{G}$. John Ikenberry, "Power and Liberal Order: America's Postwar World Order in Transition," International Relations of the Asia-Pacific, Vol. 5, No. 2 (2006), pp. 133-152. 
"following the flow," this paper explores the reasons why China is seemingly supporting the liberal international order instead of seizing the opportunity to materially revise the order or establish a China-led one.

\section{The Myth of Trump's Global Retreat}

Since the first day of his presidency, Donald Trump's "America First" doctrine has triggered concerns about whether the United States would withdraw from playing a leadership role in global governance. Notably, in his pursuit of the "America First" doctrine, President Trump vowed to prioritize U.S. interests over global cooperation. For example, in his maiden presidential address to the Congress, President Trump argued, "we've spent trillions overseas ... America has spent approximately six trillion dollars in the Middle East, all this while our infrastructure at home is crumbling." 4

Combined with the U.S. withdrawal from the TPP and the Paris Agreement, it can be argued that during the Trump administration, the United States is withdrawing from its global governance leadership. President Trump seemed to confirm the withdrawal when he stated, "we will stop racing to topple foreign regimes that we know nothing about, that we shouldn't be involved with ... we don't want a depleted military because we're all over the place fighting in areas that we shouldn't be fighting in." 5 By further suggesting that U.S. allies should protect themselves if they are not willing to pay a fair share for their defence and security, there is hint of a U.S. transition from a hegemonic outlook of global governance, which poses an "existential challenge to the internationalist project that has animated U.S. grand strategy since World War II."'6

4"Read Full Transcript of Donald Trump's First Presidential Address to Congress,"Guardian, March 1, 2017, https://www.theguardian.com/us-news/2017/feb/28/fulltranscript-donald- trump-presidential-address-congress.

5 "Donald Trump: We Will Stop Racing to Topple Foreign Regimes," Guardian, December 7, 2016, https:/www.theguardian.com/us-news/2016/dec/07/donald-trump-wewill-stop-racing-to-topple-foreign-regimes.

${ }^{6} \mathrm{Hal}$ Brands, “U.S. Grand Strategy in an Age of Nationalism: Fortress America and its Alternatives,"Washington Quarterly, Vol. 40, No. 1 (2017), pp. 73-94. 
Part of President Trump's argument for that transition is that the United States, contrary to popular belief, has not benefited from the order it created. He contends that other countries, such as China, Japan, and NATO members, have reaped economic and security benefits at the expense of the United States, leading to a decline in its economic preeminence and global influence. The notion of a declining United States that Trump advances, albeit Barack Obama and Hillary Clinton's protestations, is not without scholarly backing. Noam Chomsky argues that the United States is a global power in decline. ${ }^{7}$ Fareed Zakaria contends that we are in an era characterized by the "rise of the rest" and the dawn of the Pax Americana epoch. ${ }^{8}$ Oliver Stuenkel ${ }^{9}$ goes as far as to suggest a post-Western order, in which non-Western global powers contribute to building a multipolar order or alternatively a multiplex world order as suggested by Amitav Acharya. ${ }^{10}$

If indeed the world is transitioning from a unipolar to multipolar order, then President Trump's emphasis on "America First" is either a tactical withdrawal by a declining global power, or total abandonment of the U.S. global leadership role. Mr. He Yafei, former Vice-Minister of the State Council Office of Overseas Chinese Affairs, described it as "an overall American strategic retrenchment that focuses more on domestic political and economic concerns with an ever more inward-looking approach to international affairs." ${ }^{11}$ Nonetheless, even if the United States "withdraws" itself from world affairs and re-calibrates its foreign policy orientation, there is

The meaning of Trump's "America First" doctrine to the U.S. global leadership is debatable.

\footnotetext{
${ }^{7}$ Noam Chomsky, “American Decline: Causes and Consequence," Al Akhbar, August 24, 2011, https://chomsky.info/20110824/.

${ }^{8}$ Fareed Zakaria, The Post-American World: And the Rise of the Rest (New York: Penguin Books, 2011).

${ }^{9}$ Oliver Stuenkel, Post-Western World: How Emerging Powers are Remaking Global Order (Cambridge: Polity, 2016).

${ }^{10}$ Amitav Acharya, The End of the American World Order (London: Polity Press, 2014).

${ }^{11}$ He Yafei, "Make Globalization Great Again," China-US Focus, November 24, 2016, http://www.chinausfocus.com/foreign-policy/make-globalization-great-again.
} 
much need for caution against prematurely concluding that such "isolationist" tendencies signal the U.S. inevitable decline.

If President Trump's "America First" doctrine aims at redirecting U.S. resources toward consolidating its economic and military preponderance, it may enable the United States to consolidate and build a more sustainable global dominance, albeit in a much more multipolar world order. The tactical withdrawal from certain global responsibilities may also enable the United States to re-calibrate its global policies and reallocate its resources toward more strategic interests. John Mearsheimer and Stephen Walt describe this strategic re-calibration and reallocation of resources as offshore balancing, $^{12}$ the basis of which is that a state's economic and military capabilities are a precursor to its global expansion and engagement, and they are essential to maintaining global dominance. If the "America First" doctrine aims to achieve that, then the tactical withdrawal by the United States from non-strategic international responsibilities may actually enable it to "husband its strength, preserve U.S. primacy far into the future, and safeguard liberty at home." ${ }^{13}$

If the "America First" doctrine means isolationism, however, then the combination of a declining domestic economy and national power - plus a reputation of betraying various traditional international allies in not contributing positively to global governance - will be catastrophic to the U.S. global leadership. Hal Brands calls this version of "America First" the "Fortress America," because it represents hard-line economic nationalism, American sovereignty plus unilateralism at the expense of multilateralism, retraction of overseas commitments, self-regarding defence policy, and a pragmatic approach to alliances and promotion of democracy and human rights abroad. ${ }^{14}$ This model of "America First" will rest "on a nearly zerosum logic of global affairs ... [and] entails an explicit rejection of America's positive-sum, internationalist project, and a reversion to more narrowly nationalistic policies that carry the distinct echoes of the 1930s and even before." ${ }^{15}$ The effect is de-legitimization of the U.S. global leadership and

${ }^{12}$ John J. Mearsheimer and Stephen M. Walt, "The Case for Offshore Balancing: A Superior U.S. Grand Strategy," Foreign Affairs, Vol. 95, No. 4 (July/August 2016) pp. 70-83.

${ }^{13}$ Ibid.

${ }^{14}$ Hal Brands, "U.S. Grand Strategy in an Age of Nationalism."

${ }^{15}$ Ibid. 
degeneration of the liberal international order, giving opportunities to nonWestern rising powers to question its universality and legitimacy.

Indeed, both options, tactical withdrawal or isolationism, will require the United States to shrink from several global duties. That withdrawal, as already demonstrated by the U.S. pullout from multilateral arrangements and the decision to cut foreign aid and withhold funding for such United Nations (UN) agencies as the United Nations Population Fund (UNFPA) and the United Nations Educational, Scientific and Cultural Organization (UNESCO), has exposed a "global governance deficiency"16 that can potentially be exploited by non-Western rising powers like China.

\section{Is China a Revisionist Power?}

As the global order transitions from a U.S. unipolarity to a multipolar global order, China is emerging as the main economic, diplomatic, and military competitor to the United States, although it "continues to lag far behind the U.S. militarily." ${ }^{17}$ The U.S. Department of Defence (DoD) even forecasted that "over the long term, China's emergence as a regional power will have the potential to affect the U.S. economy and our security in a variety of ways." ${ }^{18}$ Indeed, the diminishing leadership role of the United States has provided a good window of opportunity for China to advance its own cause. Already, Chinese officials consider Beijing to be playing a prominent and decisive role in global affairs as the U.S. frontiers of dominance recede.

China's role in and engagement with the liberal international order have been a subject of notable scholarly and policy analysis. For starters, China is one of the biggest beneficiaries of the current global order.

Benefiting from the liberal world order, China lacks the incentive to fully revise it or replace it with a new one.

${ }^{16} \mathrm{He}$, "Make Globalization Great Again."

${ }^{17}$ Paul Heginbotham, The U.S.-China Military Scorecard: Forces, Geography and the Evolving Balance of Power, 1996-2017 (California: RAND, 2015).

18“Sustaining U.S. Global Leadership: Priorities for 21st Century Defense," U.S. Department of Defense, January, 2012, http://archive.defense.gov/news/Defense_Strategic _ Guidance.pdf. 
It integrated into the "order with a speed and intensity rarely seen in the developing world ... [opening] itself up to international investment, international trade, and transnational production to such a degree that China is essentially playing by our (Western) rules."19 ${ }^{19}$ President Xi even described China's global engagement as a strategic decision to benefit from being part of the liberal international order.

For many international relations scholars from the West, Beijing's ardent advocacy of the liberal order sounds paradoxical. John Mearsheimer and David Lampton consider China to be a revisionist power seeking to challenge the existing international order so as to establish a parallel order, or, at the least, materially revise the existing one. ${ }^{20}$ Martin Jacques succinctly argues in his aptly titled book, When China Rules the World: The End of the Western World and the Birth of a New Global Order, that as China uses "its new-found economic strength for wider political, cultural and military ends," it is "surely" becoming a hegemonic power. ${ }^{21}$ He holds that China will ultimately seek to revise the current global order; therefore, it will be a spoiler in Schweller's terminology. ${ }^{22}$ While Jacques agrees that China will be absorbed and integrated into the current American international order, he posits that "given that China promises to be so inordinately powerful and different, it is difficult to resist the idea that in time its rise will herald the birth of a new international order." ${ }^{23}$ Therefore, according to Martin Jacques, even if it may not be a spoiler now, China will inevitably become one as its relative material capabilities continue to increase.

Admittedly, China's relative economic power has been on an upward trajectory. In February 2017, it overtook the United States to become

${ }^{19}$ Thomas Christensen, The China Challenge: Shaping the Choices of a Rising Power (New York: W. W. Norton \& Company, 2015).

${ }^{20}$ John J. Mearsheimer, “The Gathering Storm: China's Challenge of US Power in Asia," Chinese Journal of International Politics, Vol. 3, No. 4 (2010), pp. 381-396; and David M. Lampton, “China: Challenger or Challenged?," Washington Quarterly, Vol. 39, No. 3 (2016), pp. 107-119.

${ }^{21}$ Martin Jacques, When China Rules the World: The End of the Western World and the Birth of a New Global Order (New York: The Penguin Press, 2009), p. 12.

${ }^{22}$ Randall Schweller, "Rising Powers and Revisionism in Emerging International Orders," Russia in Global Affairs, October 7, 2015, http://eng.globalaffairs.ru/valday/RisingPowers-and-Revisionism-in-Emerging-International-Orders-17730.

${ }^{23}$ Jacques, When China Rules the World, p. 16. 
Germany's biggest trading partner. It has also cultivated strong economic interests in Africa, Latin America, and the vast Asia-Pacific region. Furthermore, China established alternative multilateral institutions such as the Asian Infrastructure Investment Bank (AIIB), which rival dominant multilateral financial institutions like the Asian Development Bank (ADB). Although its military budget of approximately US $\$ 230$ billion in 2017 (according to official Chinese data) is little more than a third of that of the United States (roughly US\$580 billion), China's assertiveness in the South China Sea demonstrates a power increasingly confident of its capabilities.

The puzzle that is still unfolding and not yet significantly examined is: if China is a revisionist power with "hegemonic" ambitions, why is it seemingly not taking advantage of the upheaval in the liberal international order to materially revise the order or set up a new one of its own? In answering the question, some institutional liberals and realists contend that China is a deeply embedded beneficiary of the current international order. Joseph Nye adds that despite its growing economic power, China lacks the wherewithal to establish an alternative global order. ${ }^{24}$ In concurrence, Jonathan Fenby maintains that China does "not have the economic, political and human resources to dominate the world, even if it wished to do so," because it lacks the required resources. Particularly, China does not "have the political capacity to exercise the kind of leadership that is needed" to establish and maintain an alternative global order. ${ }^{26}$

Likewise, G. John Ikenberry suggests that China is a supporter of the order simply because it does not have the capacity to challenge the United States. ${ }^{27}$ It also does not have the wherewithal to operate an alternative global order, especially a global economic order. The combined effect of socialization and lack of resources and political capacity is, according to Ikenberry, the reason why, instead of replacing the liberal international order with its own global order, China will continue to be absorbed into the

${ }^{24}$ Joseph S. Nye, Is the American Century Over? (Cambridge: Polity, 2015).

${ }^{25} J o n a t h a n$ Fenby, Will China Dominate The 21st Century? (Cambridge: Polity, 2014), p. 26.

${ }^{26}$ Henry Kissinger, Niall Ferguson, Fareed Zakaria and David Daokui Li, Does the 21st Century Belong to China? The Munk Debate on China (Toronto: House of Anansi, 2011).

${ }^{27}$ G. John Ikenberry, "The Future of Liberal World Order," Japanese Journal of Political Science, Vol. 16, No. 3 (2015), pp. 450-455. 
existing order. ${ }^{28}$ Furthermore, as Barry Gills and Heikki Patomäki conclude, even if the United States abandons the liberal international order, the order's common institutions "may well continue to exist and function after hegemony, in a decentralized way through extended, bendable and institutionally insured tit-for-tat strategies." ${ }^{29}$

Citing a different reason, Thomas Christensen argues that for China, the cost of changing the system is too prodigious compared to the benefits of operating within its current confines, which makes China a de facto supporter of the current global order. As he puts it, "now that it is so deeply entrenched, why would China want to change international trade and financial institutions fundamentally, particularly when it has been doing so well within that system?"30

The challenge with the above two contrasting explanations of China's rise vis-a-vis the liberal international order is that they explain more about the West than they do about China. They focus on "constants rather than variables" $^{\prime 31}$ and put more emphasis on Euro-centric principles of power transition and balance of power than they do on China's "understandings" of the meaning and purpose of global power and influence. Rather than being preoccupied with explaining China's global power ambitions on the premise of realpolitik, and a balance of power policy based on threats of military force and direct confrontation in determining winners and losers in the struggle for global dominance, David Daokui Li cautions that we should

... look at the lens of traditional Chinese philosophers, the Confucians. The Confucians advocated for a harmonious world in which ... countries are working with each other to solve international conflicts ... the

${ }^{28}$ G. John Ikenberry, "The Rise of China and the Future of the West: Can the Liberal System Survive?," Foreign Affairs, January/February, 2008, https://www.foreignaffairs.com/ articles/asia/2008-01-01/rise-china-and-future-west.

${ }^{29}$ Barry Gills and Heikki Patomäki, “Trumponomics and the 'Post-Hegemonic' World," Real-World Economics Review, Vol. 79, (2017), pp. 92-93.

${ }^{30}$ Ibid.

${ }^{31} \mathrm{He}$ Kai, "Explaining United States-China Relations: Neoclassical Realism and the Nexus of Threat-Interest Perceptions," The Pacific Review, Vol. 30, No. 2, (2017), p. 135. 


\section{1st century will belong to China and also will belong to any countries, any nations or peoples who are willing to follow the flow. ${ }^{32}$}

Although we may not entirely subscribe to his exclusive focus on Confucius traditions as main influencers of Chinese foreign policy, Li introduces an alternative explanation to China's paradoxical response and approach to current upheavals in the liberal international order. The phrase "follow the flow" well encapsulates that explanation.

To "follow the flow" implies eschewing the fixity of grand strategies and following the natural evolution of events without forcing a particular outcome. Chinese President Xi Jinping once gave a hint of what "following the flow" would possibly look like in real-life foreign policy practice. As he said, "one must

China has a fixed goal of national revival by a flexible and pragmatic approach. understand the trend of time, devise strategy and plan carefully." ${ }^{33}$ In that sense, observing the trend of time precedes devising a strategy or even careful planning. This implies that a state does not push against prevailing global trends, behaviors and norms; rather, it observes the trend, and then makes pragmatic and flexible strategies that suit prevailing trends. The flexibility and fluidity of this approach does not imply the absence of Beijing's plan for its future in the international system. It simply suggests that China is opting for flexibility and maneuverability to achieve its global power ambitions "of 'grand renaissance', aimed at a return to China's view of the regional status quo of pre-1840s colonial and subsequent Western domination. ${ }^{\prime 34}$ If successful, the strategy can enable China to engage in "an outward-oriented pragmatism designed to rapidly ... improve its standing and influence in the international political order" ${ }^{\prime 35}$ while avoiding the related costs.

${ }^{32}$ Kissinger, Ferguson, Zakaria and Li, Does the 21st Century Belong to China?

33 "Xi Jinping: China to Further Friendly Relations with Neighboring Countries," People's Daily October 26, 2013, http://en.people.cn/90883/8437410.html.

${ }^{34}$ Zhang Xiaotong and James Keith, "From Wealth to Power: China's New Economic Statecraft," Washington Quarterly, Vol. 40, No. 1 (2017), pp. 185-203.

${ }^{35}$ Michael D. Swaine and Ashley J. Tellis, Interpreting China's Grand Strategy: Past, Present, and Future (Washington D.C.: RAND, 2000). 
When following the flow, China's foreign policy interests and objectives are the objects of fixity, yet the global environment in which they are practiced remains fluid and evolving. Following the flow, therefore, exemplifies the ability of China's fixed foreign policy objectives and interests to adapt and take advantage of the volatile flow of global developments, such as Trump's presidency, Brexit, and growing populism in the West. In turn, this ability to adapt and take advantage of the flow determines whether China will have any consequential effect on the liberal international order. Accordingly, the rise of China will be "a dynamic process, in which many changing material and ideational factors will shape policy choices of states as well as interactions among them.." ${ }^{\prime 36}$

While China is on its way to a new global leadership role, there is need for an understanding of what China will do with its new-found global power in the context of the current liberal order upheavals. In his book entitled After Victory: Institutions, Strategic Restraint and the Rebuilding of Order after Major Wars, G. John Ikenberry posits that after achieving victory in a major war, the emergent victor has three choices:

\begin{abstract}
It can dominate - use its commanding material capabilities to prevail in the endless conflicts over distribution of gains. It can abandonwash its hands off post-war disputes and return home. Or it can try to transform its favorable post-war power position into durable order that commands the allegiance of the other states within the order. ${ }^{37}$
\end{abstract}

Whereas Ikenberry envisioned the three choices in the context of a state emerging victorious from a major war, the current international order upheaval is not a result of war but internal convolutions within the current global order that have caused its architects to consider withdrawing or abandoning their global governance responsibilities.

In the turmoil that has followed Brexit, election of Donald Trump as U.S. President and the rise of ultranationalism in Europe, China seems to be positioning itself to replace the United States as a global leader. Niccolò Machiavelli speaks of the virtu to prepare for fortuna, or unexpected

${ }^{36} \mathrm{He}$, "Explaining United States-China Relations."

${ }^{37} \mathrm{G}$. John Ikenberry, After Victory: Institutions, Strategic Restraint and the Rebuilding of Order after Major Wars (Princeton: Princeton University Press, 2001), p. 4. 
opportunity that might come along. ${ }^{38}$ As put by Yao Yang, Dean of the National School of Development at Peking University, "it just happens that Mr. Trump's retreat from global governance is [being] met by China's ambition to move to the central stage of world affairs." ${ }^{39}$ Beijing might not have anticipated the effects of Trump's presidency, but it seems keen on leveraging the opportunities this presents to advance its global ambitions. To some extent, these international developments (Brexit, populism in Europe and Trump's presidency) fit into China's "period of strategic opportunity." Xu Jian of the China Institute of International Studies (CIIS) defines the "period of strategic opportunity" as "the duration of time during which the comprehensive national strength, international competitiveness and influence of a country are expected to rise consistently as a result of favorable subjective and objective factors." ${ }^{40}$

Yet, how exactly will China take over global power from the United States? Contrary to Ikenberry's explanation, the United States has not lost a major war; neither has China won a major war nor triumphed over the United States militarily. The implication is that for China, there is no victory to celebrate; hence, there is no decisive entry into global leadership. There is also no telling whether the United States will continue on the same with-

The Chinese leadership remains cautious to the seeming opportunities created by current liberal order upheavals. drawal trajectory during the potentially erratic Trump's presidency or after. As there is no decisive transition of power, China seems to focus on following the flow whilst building its competence to "sense and take chances, to expand or even shape opportunities when

${ }^{38}$ Niccolò Machiavelli, The Prince and the Discourses. Translated by Luigi Ricci (New York: Modern Library, 1950).

${ }^{39}$ Yao Yang, "US-China Race to Dominate Global Governance Must be Avoided," Financial Times, March 1, 2017, https://www.ft.com/content/123620ac-fe90-11e6-8d8ea5e3738f9ae4.

${ }^{40} \mathrm{Xu}$ Jian, "Rethinking China's Period of Strategic Opportunity," China Institute of International Studies, May 28, 2014, http://www.ciis.org.cn/english/2014-05/28/content_ 6942258.htm. 
favorable conditions arise." ${ }^{41}$ Previously, China failed to utilize such opportunities, because it was "confined by its social conditions and ways of thinking at the time; China failed to realize that the Industrial Revolution was a great opportunity for human progress and national development." ${ }^{\prime 2}$ The paradox, however, is that instead of taking the opportunity of America's "withdrawal," and capitalizing on the current Western disenchantment with the liberal international order, China seems reluctant to build its own international order but prefers to protect the liberal international order and its globalization project.

\section{China's Approach to Global Leadership}

In acknowledgement of the U.S. supremacy in the balance of power rather than the balance of influence, China has consistently argued that it does not intend to take over global leadership from the United States. Chinese international relations scholars also assert - and correctly so - that China is still far from being able to assume a global leadership position. However, that does not mean China has no global leadership ambitions. As Ye Zicheng argues, "If China does not become a world power, the rejuvenation of the Chinese nation will be incomplete. Only when it becomes a world power can we say that the total rejuvenation of the Chinese nation has been achieved." ${ }^{\prime 3}$ On the surface, however, President Xi's speech at the 2017 World Economic Forum (WEF) in Davos leaves us an impression of a China concerned about maintaining the current liberal international order, suggesting that China is not directly taking advantage of the upheaval in the liberal international order. This might appear puzzling because amidst the U.S. and European nationalists' vitriol against globalization, China has confirmed its commitment to safeguarding globalization.

The puzzling Chinese approach to global power distribution within the current global order has its roots in President Xi's "Chinese Dream" notion. Since coming to power in 2012, President Xi has been advocating for a new model of major-power relations (xinxing daguo guanxi).

${ }^{41}$ Ibid.

${ }^{42}$ Ibid.

${ }^{43}$ Ye Zicheng, Inside China's Grand Strategy: The Perspective from the People's Republic (Lexington: The University Press of Kentucky, 2011), p. 74. 
A constructive and non-antagonistic relationship with the United States is unarguably crucial to Beijing in realizing national rejuvenation and the Chinese Dream. Accordingly, when it comes to relations with the United States, President $\mathrm{Xi}$ favors an approach that encourages mutual respect, cooperation, a fair balance of global power distribution and recognition of China as an equal partner to the United States. President Xi's approach essentially reflects his pragmatism in international politics because he recognizes the importance of the existing liberal international order to China's economic modernization and advancement. In China's various international initiatives, one can see that it is in many ways trying to mimic the United States. For instance, the AIIB is modeled and structured along the same lines as the World Bank. Former World Bank officials also administer it, albeit with slight changes that enable the institution to serve China's global ambitions better.

President Xi's strategy of minimizing direct conflict with the United States is to appear supportive to the liberal international order and dispel suspicions that the current upheavals are giving China an opportunity to try on "the mantle of global leadership ... [and] step up as a champion of free trade and protector of the global environment." ${ }^{44}$ For instance, as President Xi stated at the 2017 WEF,

[A]ll countries enjoy the right to development. At the same time, they should view their own interests in a broader context and refrain from pursuing them at the expense of others ... [W] must remain committed to developing global free trade and investment, promote trade and investment liberalization and facilitation through opening-up and say no to protectionism. Pursuing protectionism is like locking oneself in a dark room. While wind and rain may be kept outside, that dark room will also block light and air. No one will emerge as a winner in a trade war. ${ }^{45}$

44Jane Perlez and Chris Buckley, “Trump Injects High Risk into Relations with China," New York Times, January 24, 2017, https:/www.nytimes.com/2017/01/24/world/asia/trumpus-china-trade-trans-pacific-partnership.html?_r=0.

45 “Full Text of Xi Jinping Keynote at the World Economic Forum," CGTN America, January 17, 2017, https://america.cgtn.com/2017/01/17/full-text-of-xi-jinping-keynote-at-theworld-economic-forum. 
At the 24th Asia-Pacific Economic Cooperation (APEC) Summit held in Lima, Peru in November 2016, President Xi outlined China's strategy to promote free global trade. Compared with President Trump's argument that globalization was the root cause of America's decline or remarks by Marine Le Pen, a French far-right leader, that "our leaders chose globalization, which they wanted to be a happy thing. It turned out to be a horrible thing, ${ }^{\prime 46}$ President $\mathrm{Xi}$ appears to be the one fighting for the liberal international order today.

On the one hand, by appearing to support globalization and free trade, China is setting the parameters for its contest with the United States for legitimacy and global influence. This is because China has benefited immensely from globalization and free trade to the extent that it has become the biggest trading partner of most European, Asian and African countries. By supporting globalization, it portrays itself as concerned about sharing its

China appears to strongly uphold the liberal international order today. economic wealth with the rest of the world, particularly the developing world.

Beijing chooses to focus on economic matters such as free trade and globalization rather than geostrategic and military matters that the United States still dominates in. Unlike its military capabilities, China's relative economic capabilities are increasingly comparable to the United States. As put by Edward Luttwak, the focus on economic issues displaces the logic of military and geopolitical conflict, "which is adversarial, zero-sum, and paradoxical." 47 Accordingly, by following the trend of a global disconcert over Western populism, China's strategy is to reverse the overshadowing of the "economic realm by strategic priorities and strategic modalities" ${ }^{48}$ dominated by the United States, because "as the relevance of military threats and military alliances wanes, geoeconomic priorities and

${ }^{46}$ Nicholas Vinocur, "Marine Le Pen Makes Globalization the Enemy," Politico, February 5, 2017, http://www.politico.eu/article/marine-le-pen-globalization-campaign-launchfrench-politics-news-lyon-islam/.

${ }^{47}$ Edward N. Luttwak, “From Geopolitics to Geo-economics: Logic of Conflict, Grammar of Commerce," National Interest, Vol. 20 No. 20 (1990), pp. 17-23.

${ }^{48}$ Ibid., p. 20. 
modalities are becoming dominant in state action." 49 Thus, in appearing to support globalization and oppose the U.S. protectionism, China is carefully "riding the wave" in a manner that makes it a preferred leader in global economic governance.

Meanwhile, China's posture as a protector and guarantor of globalization and the liberal international system sums up Sun Tzu's statement: "the opportunity of defeating the enemy is provided by the enemy himself." 50 Keen to be anti-establishment, President Trump has constantly questioned the purpose and relevance of the liberal international order and America's role in it. From questioning the global economic order to causing uncertainty among European and Asia-Pacific allies, President Trump has rattled trust and confidence in the U.S. global leadership. The extent of President Trump's mistake in publicly questioning the liberal international order, which is an embodiment of American values, is such that Iran's supreme leader Ayatollah Ali Khamenei tweeted, "We appreciate Trump! Because he largely did the job for us in revealing the true face of America." ${ }^{51} \mathrm{He}$ also added, "what we've been saying in thirty some years of corruption in U.S. government, Trump has outspokenly said during his campaign and in office." ${ }^{52}$

As Francis Fukuyama told The Washington Post, "when democracies start turning on themselves and undermining their own legitimacy, then you're in much more serious trouble." ${ }^{53}$ Similarly, in his farewell speech, President Obama stated that the post-World War II order that the United States had built together with other democracies, which was "based not just on military power or national affiliations, but built on principles, the rule of

${ }^{49}$ Ibid., p. 20.

${ }^{50}$ Sun Tzu, The Art of War. Translated by Lionel Giles (The Puppet Press, 1910), p. 53. http://www.puppetpress.com/classics/ArtofWarbySunTzu.pdf.

${ }^{51}$ Ayatollah Seyed Ali Khamenei, @khamenei_ir, February 7, 2017, https://twitter.com/ khamenei_ir/status/828960560087707648.

${ }^{52}$ Ayatollah Seyed Ali Khamenei, @khamenei_ir, February 7, 2017, https://twitter.com/ khamenei_ir/status/828962391958380546.

${ }^{53}$ Ishaan Tharoor, “The Man Who Declared the `End of History' Fears for Democracy's Future," Washington Post, February 9, 2017, https://www.washingtonpost.com/news/world views/wp/2017/02/09/the-man-who-declared-the-end-of-history-fears-for-democracysfuture/?utm_term=.eb1327eeb3e2. 
law, human rights, freedom of religion and speech and assembly and independent press ... is now being challenged." ${ }^{54}$ Slavoj Zizek, a philosopher and cultural critic said "one good thing about Donald Trump - and it's an obscenity to call this a good thing — is that he put [the system] into great disarray." ${ }^{\prime 55}$ By putting the liberal international system and the U.S.' network of allies into disarray, the Trump administration is making a "suicidal mistake." In simple terms, Beijing's strategy is to let the United States continue on its path of self-destruction based on a belief that whatever destroys the legitimacy of the United States as a global power shores up China's global influence.

\section{China is patiently}

waiting for the U.S.'

self destruction

before asserting its

global leadership.

In appearing to support the values and principles of the liberal international order that the United States is challenging, China is delegitimizing the United States. When Donald Trump withdrew America's support for the Paris Agreement, China seized the opportunity to cast itself into leadership of the global climate governance. At the 22nd Conference of Parties to the UNFCCC (COP22) held in Marrakesh, Morocco in November 2016, China laid out its plan for combating climate change and announced the South-South Climate Cooperation Fund. Similarly, when the United States withdrew from the TPP arguing that it was going to take American jobs, China emphasized the need to expedite negotiations on the APEC Free Trade Agreement.

In regard to the TPP, the Australian Prime Minister even suggested that the remaining 11 signatories ${ }^{56}$ without the United States continue with a possible admission of Beijing. Even if Beijing does not end up a member of

${ }^{54}$ Barack Obama, “President Obama: The TPP Would Let America, Not China, Lead the Way in Global Trade," Washington Post, May 2, 2016, https://www.washingtonpost.com/ opinions/president-obama-the-tpp-would-let-america-not-china-lead-the-way-on-global-trade/ 2016/05/02/680540e4-0fd0-11e6-93ae-50921721165d_story.html?utm_term=.89cf62c560cd.

55 “Zizek: Electing Trump will 'Shake Up’ The System," Al Jazeera, November 16, 2016, http://www.aljazeera.com/programmes/upfront/2016/11/zizek-electing-trump-shake-system161116062713933.html=.

${ }^{56}$ The original 12 countries are Australia, Brunei, Canada, Chile, Japan, Malaysia, Mexico, New Zealand, Peru, Singapore, Vietnam, and the United States (withdrawn). 
the TPP, a mere suggestion by a U.S. ally that Beijing should be included suggests the loss of trust and confidence in the United States. Accordingly, "the demise of TPP leaves no viable alternative to the default Chinese position of trade liberalization, primarily in goods, backed by strong mercantile governments. President Trump's canceling of the TPP was a gift to China." ${ }^{\prime 57}$ China's support for globalization and the climate change deal, as well as offering alternatives to the TPP, is calculated to prove that China is a more reliable partner than the United States, feeding into an already existing concern among U.S. allies over the direction of the U.S. foreign policy under the Trump administration.

On the other hand, China is maintaining its "peaceful development" narrative and scaling up its efforts in sharing ideas on how a fair and just global governance system can be established. By following the flow, China is expected to foster "contingent cooperation with the major powers while seeking to reassure nervous neighbors." ${ }^{158}$ In doing that, Beijing is able to dispel the "China threat theory" while fostering a conducive environment for its economic and global influence growth. In that respect, while the United States withdraws from some multilateral arrangements, China is strengthening its multilateral engagement in institutions such as the BRICS (a mainly economic coalition among Brazil, Russia, India, China and South Africa), APEC, and the Group of Twenty (G20), giving an impression that China is committed to multilateralism even if it may not be in its best interest. In other words, whilst the United States is demonstrating that it does not want to be constrained by multilateral rules in a rule-based global system, China is committing itself to constraining its growing relative power for the benefit of other countries, especially those in the Global South. According to He Yafei, by participating in these multilateral institutions, China is demonstrating global leadership through "proactive discussions about and negotiations on safeguarding global governance system while advocating needed changes to make the system better suited for the

${ }^{57}$ Barry Naughton, "Xi Jinping's Economic Policy in the Run-Up to the 19th Party Congress: The Gift from Donald Trump," China Leadership Monitor, Vol. 52 (Winter 2017), p. 6, http://www.hoover.org/sites/default/files/research/docs/clm52bn.pdf.

${ }^{58}$ Avery Goldstein, Rising to the Challenge: China's Grand Strategy and International Security (Stanford: Stanford University Press, 2005), p. 203. 
emerging new era of globalization." ${ }^{59}$ By appearing to support rules of the liberal international order, China is gradually establishing itself as a benign power in its immediate neighborhood and beyond.

Speaking at a diplomatic conference in 2013, President Xi told Chinese diplomats that

... we should clearly present our policies to the outside world, tell China's story in an acceptable way, speak out so that we are heard, and interpret the Chinese dream from the perspective of the aspiration of all people in all countries for a better life and regional prosperity, and let the sense of common destiny take root with our neighbors. ${ }^{60}$

In this sense, China appears not to be seeking a coercive order imposed by the powerful but a consensual order "undergirded by some mixture of rationalist calculations of material self-interest and convergent values, affinities, and identities." 61

In Chinese media editorials and opinion columns, the discourse on China's role in building a "new" global governance system that best suits its interests and ideals is gaining popularity. At the same time, other columnists in Chinese media are also quick to caution against "current debates mainly focusing on China's rising role and how the vacuum created by the U.S. withdrawal from global engagement can be fulfilled. Such discussions, however, are not constructive because they are based on zero-sum game stereotypes." ${ }^{62}$ Beijing's aim is not to enthrone itself, but to be enthroned by other countries as the global leader of the emerging multipolar global system. In that way, China earns the respect of countries in the Global South and the West as an unassuming global power that is not keen on imposing its will on other states.

${ }^{59} \mathrm{He}$, “Make Globalization Great Again."

60 "Xi Jinping: China to Further Friendly Relations with Neighboring Countries," Xinhua News, October 26, 2013, http://news.xinhuanet.com/english/china/2013-10/26/ c_125601680.htm.

${ }^{61}$ Patrick, “World Order: What, Exactly, Are the Rules?," p. 9.

${ }^{62} \mathrm{Fu}$ Jing, “China, EU and US Should Work Together," China Daily, February 14, 2017, http://www.chinadaily.com.cn/opinion/2017-02/14/content_28189621.htm. 
Signs are already emerging. For instance, in February 2017, members of the African Elephant Coalition (AEC) urged the EU to emulate China in banning ivory products. The AEC Chairman Patrick Omondi said, "we need other countries with legal domestic markets to follow suit and are calling on the EU to take advantage of the momentum created by China and shut down their trade and ivory once and for all." ${ }^{63}$ As then Ethiopian Prime Minister Hailemariam Desalegn told The Wall Street Journal, "China has become a model not only for Ethiopia but now even the new administration of the United States ... They are focused on bringing back jobs and manufacturing to the U.S., which obviously means the Chinese drive to have manufacturing at home has become a model even for the U.S." ${ }^{64}$ Accordingly, instead of challenging globalization, China is taking concrete steps toward consolidating it.

\section{Conclusion}

China's approach of following the flow aims at creating a conducive environment for its continued economic growth and expanding global influence while repelling the China threat theory. Following the flow also gives China "the breathing room it needs to improve domestic social conditions, increase the legitimacy of the governing regime, expand the nation's economic and technological capabilities, strengthen its military, and enhance its standing and influence in the international political order." ${ }^{\prime 65}$ If China can maintain its economic growth and national power, it will certainly become a strong global power under President Xi's leadership, and increase its ability to fill the global governance deficiency caused by President Trump's "America First" doctrine.

President Xi still has five years to do his job; and with presidential term limits removed, he is poised to rule China for a much longer period of time. Regardless of how long President $\mathrm{X} i$ remains in power, China's

63“African Nations Urge EU to Emulate China's Ivory Trade Ban," Xinhua News, February 4, 2017, http://news.xinhuanet.com/english/2017-02/05/c_136033134.htm.

${ }^{64}$ Matina Stevis, “Ethiopian Premier, a China Ally, Calls Beijing a Model for U.S. on Job Growth," February 2, 2017, https://www.wsj.com/articles/ethiopian-premier-a-china-allycalls-beijing-a-model-for-u-s-on-job-growth-1486065701.

${ }^{65}$ Swaine and Tellis, "Interpreting China's Grand Strategy." 
authoritarian political system makes it easier to continue its governing path and advance its international posture even if a new leader comes into office. What is less certain is the foreign policy trajectory in the United States. As noted previously, if President Trump successfully re-calibrates America's relative power and sustain its hegemonic influence, albeit in a multipolar environment, China may change its "reactive" approach, and there might be more confrontation between the United States and China. However, if President Trump fails in his "America First" doctrine, leading to the decline of both America's hard and soft power internationally, then China's approach of following the flow will prove even more effective. 